\title{
MENINGKATKAN HASIL BELAJAR MATEMATIKA PADA SISWA MELALUI PEMBELAJARAN MATEMATIKA REALISTIK
}

\author{
Uus Susnariah \\ SDN Cigintung Kuningan, Indonesia \\ uussusnariah@gmail.com
}

\begin{abstract}
Mathematics is a very important subject because it is useful in solving everyday problems. However, several study results reveal that many students still have difficulties in learning mathematics, which has an impact on their low learning outcomes. The same situation occurs in SDN Cigintung Kuningan, where students' learning completeness in mathematics is very low. One effort that can be done is by applying the right learning model. Realistic Mathematics Learning is one of the learning models that is thought to be appropriate to be applied to improve student learning outcomes, because this model implements mathematics learning in real life. The purpose of this study is to improve student learning outcomes through Realistic Mathematics Learning. This research is a classroom action research with the subject of this study is students of class VI A SDN Cigintung, Kuningan in the academic year 2019/2020. The results showed an increase in student learning outcomes from pre cycle to cycle II. So it can be concluded that realistic learning can improve student learning outcomes in mathematics.
\end{abstract}

Keywords: learning outcomes, mathematics, realistic mathematics learning

\begin{abstract}
ABSTRAK
Matematika merupakan mata pelajaran yang sangat penting karena berguna dalam menyelesaikan permasalahan sehari-hari. Namun beberapa hasil studi mengungkap bahwa banyak siswa yang masih kesulitan dalam belajar matematika sehingga berdampak pada rendahnya hasil belajar mereka. Situasi yang sama terjadi di SDN Cigintung Kuningan, di mana ketuntasan belajar siswa pada mata pelajaran matematika sangat rendah. Salah satu upaya yang dapat dilakukan adalah dengan menerapkan model pembelajaran yang tepat. Pembelajaran Matematika Realistik merupakan salah satu model pembelajaran yang diduga tepat diterapkan untuk meningkatkan hasil belajar siswa, karena model ini melaksanakan pembelajaran matematika dengan kehidupan nyata. Tujuan penelitian ini adalah untuk meningkatkan hasil belajar siswa melalui Pembelajaran Matematika Realistik. Penelitian ini merupakan penelitian tindakan kelas dengan subjek penelitian ini adalah siswa kelas VI A SDN Cigintung, Kuningan tahun pelajaran 2019/2020. Hasil penelitian menunjukan terjadi peningkatan hasil belajar siswa dari pra siklus hingga siklus II. Jadi dapat disimpulkan pembelajaran realistic dapat meningkatkan hasil belajar siswa pada mata pelajaran matematika.
\end{abstract}

Kata Kunci : hasil belajar, matematika, pembelajaran matematika realistik

\begin{tabular}{l|l|l} 
Submitted Apr 5, 2020 & Revised Jun 2, 2020 & Accepted Jun 5, 2020
\end{tabular}

\section{Pendahuluan}

Mata pelajaran yang dapat diterapkan dalam kehidupan sehari-hari salah satunya adalah matematika. Matematika adalah ilmu yang memiliki peranan bagi kehidupan, konsep dalam matematika terdiri dari yang paling sederhana hingga yang paling kompleks, sistematis, logis, dan hierarkis (Nahdi \& Jatisunda, 2020). Matematika dapat menyiapkan individu dalam meningkatkan taraf hidup dan memecahkan permasalahan yang dihadapi dalam kehidupan sehari-hari. Matematika telah diberikan sejak siswa di Sekolah Dasar. Hal ini menunjukkan bahwa matematika sangat penting dalam jenjang selanjutnya. Senada dengan pendapat Prihandoko (2006: 1) bahwa matematika merupakan ilmu dasar yang sudah menjadi alat untuk 
mempelajari imu-ilmu lain. Menurut Subarinah (2006: 2), kegunaan matematika bagi siswa SD adalah sesuatu yang jelas yang tidak perlu dipersoalkan lagi, terlebih pada era pengembangan ilmu pengetahuan dan teknologi dewasa ini. Matematika dapat berfungsi mengembangkan keterampilan berhitung dengan bilangan sebagai alat dalam kehidupan sehari-hari.

Keberhasilan proses pembelajaran ditentukan oleh hasil belajar yang dicapai oleh siswa. Pembelajaran bukan menginformasikan materi agar dikuasai oleh siswa, tetapi memberikan kondisi agar siswa mengusahakan terjadi belajar dalam dirinya. Hasil belajar merupakan perubahan pada diri anak meliputi kemampuan intelektual, sikap/minat maupun keterampilan setelah mengikuti proses belajar mengajar. Kemampuan intelektual dapat diukur dengan tes hasil belajar. Siswa dapat dikatakan berhasil apabila telah mencapai Kriteria ketuntasan Minimal yang telah ditentukan pada mata pelajaran Matematika.

Dalam KTSP (2007: 143-144) tujuan mata pelajaran Matematika diberikan kepada peserta didik yaitu :

a. Memahami konsep matematika, menjelaskan keterkaitan antarkonsep dan mengaplikasikan konsep atau alogaritma secara luwes, akurat, efisien, dan tepat dalam pemecahan masalah.

b. Menggunakan penalaran pada pola dan sifat, melakukan manipulasi matematika dalam membuat generalisasi, menyusun bukti, atau menjelaskan gagasan dan pernyataan matematika.

c. Memecahkan masalah yang meliputi kemampuan memahami masalah, merancang model matematika, menyelesaikan model dan menafsir solusi yang diperoleh.

d. Mengkomunikasikan gagasan dengan simbol, tabel, diagram, atau media lain untuk memperjelas keadaan atau masalah.

e. Memiliki sikap menghargai kegunaan matematika dalam kehidupan, yaitu memiliki rasa ingin tahu, perhatian, dan minat dalam mempelajari matematika serta sikap ulet dan percaya diri dalam pemecahan masalah.

Berdasarkan pendapat di atas diungkapkan bahwa tujuan mata pelajaran Matematika salah satunya adalah pembentukan sikap siswa. Sikap merupakan suatu komponen yang sangat mempengaruhi keberhasilan pembelajaran matematika. Sikap matematika adalah ranah afektif yang sangat penting dalam menentukan perilaku siswa dalam pemikiran matematika dan pemecahan masalah.

Siswa yang memiliki sikap positif akan menunjukkan tindakan yang selalu mengarah pada upaya pencapaian tujuan pembelajaran matematika. Salah satu hal yang perlu diperhatikan oleh guru untuk keberhasilan pembelajarannya adalah menciptakan suatu kondisi pembelajaran yang dapat merangsang dan meningkatkan sikap positif siswa dalam pembelajaran matematika.

Namun pada kenyataannya, hasil observasi pertama yang dilakukan pada tanggal 31 Januari 2019 pada mata pelajaran matematika menunjukkan bahwa guru menyampaikan materi dengan metode ceramah, tanya jawab, dan diskusi. Namun guru tidak menggunakan alat peraga tetapi dalam pembelajaran tersebut guru menekankan bahwa setidaknya siswa hafal dengan materi tersebut. Padahal hafalan bukanlah solusi untuk memahami sebuah materi. Siswa juga tidak semuanya aktif dalam diskusi kelompok. Guru memberikan kesempatan kepada siswa untuk bertanya mengenai hal-hal yang belum dimengerti tetapi belum ada siswa yang berani untuk menunjukkan jari. Guru memberikan pertanyaan kepada salah satu siswa tetapi siswa tersebut tidak menjawab pertanyaan dengan tepat. Guru juga tidak mengkaitkan materi dengan lingkungan siswa. 
Observasi kedua dilaksanakan pada tanggal 16 Juli 2019 menunjukkan bahwa guru menggunakan metode ceramah dan kurang memanfaatkan alat peraga untuk menyampaikan materi pelajaran. Siswa tidak dilibatkan secara aktif dalam pembelajaran, ini terlihat pada saat pembelajaran guru langsung memberikan konsep yang sudah jadi dan meminta siswa untuk menghafalnya. Pembelajaran seperti ini akan mudah dilupakan oleh siswa karena siswa tidak menemukan sendiri konsep yang dipelajari.

Berdasarkan hasil wawancara yang dilakukan terhadap guru kelas VI A dikatakan bahwa hasil belajar matematika tergolong rendah dari mata pelajaran lainnya. Ini ditunjukkan dari data hasil ujian semester II bahwa rata-rata nilai matematika kurang dari KKM yaitu 6,5. Dari 25 siswa, hanya 4 yang sudah mencapai KKM, sedangkan nilai rata-rata kelas juga masih belum mencapai KKM yaitu hanya 5,7.

Tabel 1. Hasil rata-rata nilai UAS semester II

\begin{tabular}{cc}
\hline Mata Pelajaran & Nilai rata-rata UAS \\
\hline Matematika & 5,7 \\
IPA & 6,8 \\
IPS & 5,8 \\
PKn & 6,6 \\
Bahasa Indonesia & 6,4 \\
\hline
\end{tabular}

Sumber : Dokumentasi guru

Berdasarkan hal tersebut di atas, ketepatan dalam pemberian pendekatan pembelajaran sangat menentukan hasil belajar siswa. Dengan pendekatan pembelajaran yang tepat, siswa dapat termotivasi dan senang dengan apa yang akan guru sampaikan. Penggunaan rumusrumus matematika tanpa memahaminya hanya akan menjadi sebuah hafalan. Jika siswa mempelajari matematika hanya dengan hafalan, maka mereka tidak akan bisa menerapkan konsep atau rumus tersebut untuk menyelesaikan permasalahan sehari-hari yang mereka temukan.

Salah satu pendekatan pembelajaran yang dapat diterapkan dalam pembelajaran matematika adalah Pembelajaran Matematika Realistik. Menurut Tarigan (2006), pembelajaran ini menekankan akan pentingnya konteks nyata yang dikenal murid dan proses konstruksi pengetahuan matematika oleh murid sendiri. Pendekatan Pendidikan Matematika Realistik (RME) memperhitungkan kondisi lokal (seperti budaya, lingkungan, atau konteks) menunjukkan bahwa siswa tidak lagi takut untuk mengekspresikan ide-ide mereka, berani memberikan pemecahan masalah yang berbeda dengan teman-teman sebayanya dan menumbuhkan kreativitas mereka dalam menyelesaikan masalah secara kolaboratif (Fitriani, Suryadi, \& Darhim, 2018; Susanti \& Rustam, 2018). Pembelajaran matematika realistik sebagai kegiatan yang lebih menekankan aktivitas siswa untuk mencari, menemukan dan membangun sendiri pengetahuan yang dia perlukan sehingga pembelajaran menjadi terpusat pada siswa. Matematika realistik pada dasarnya adalah pola belajar yang memanfaatkan realitas dan lingkungan yang dipahami siswa untuk memperlancar proses pembelajaran Matematika sehingga dapat mencapai tujuan pembelajaran Matematika secara lebih baik. Pembelajaran matematika realistik dimana pembelajaran ini mengaitkan dan melibatkan lingkungan sekitar, pengalaman nyata yang 
pernah dialami siswa dalam kehidupan sehari-hari, serta menjadikan matematika sebagai aktivitas siswa. Siswa tidak harus dibawa ke dunia nyata, tetapi siswa diajak berpikir bagaimana menyelesaikan masalah yang mungkin atau sering dialami siswa dalam kesehariannya. Beberapa penelitian sebelumnya telah membahas bagaimana pembelajaran matematika realistik memberikan dampak postif terhadap pembelajaran (Atika \& Mz, 2016; Dolk \& Eerde, 2013; Hidayat \& Iksan, 2015; Rudiono, Dafik, \& Wahyuningrum, 2015) dalam meningkatkan kemampuan analogis matematis (Azmi, 2017; Rahman \& Maarif, 2014) dan penelitian yang menguji kebiasaan pikiran (Bidari, 2016; Indriani, 2018; Masni, 2017; Miliyawati, 2017; Zhok, 2016).

Berdasarkan uraian di atas, pendekatan pembelajaran yang dapat diterapkan untuk menjawab masalah tersebut adalah pendekatan pembelajaran matematika realistik. Peneliti ingin mengkaji masalah ini dengan mengadakan penelitian mengenai peningkatan hasil belajar matematika siswa kelas VI A melalui pembelajaran matematika realistik di SDN Cigintung Kecamatan Kuningan, Kabupaten Kuningan.

\section{Metode Penelitian}

Jenis penelitian ini adalah Penelitian Tindakan Kelas (PTK). Penelitian Tindakan Kelas merupakan suatu pencermatan terhadap kegiatan belajar berupa sebuah tindakan, yang sengaja dimunculkan dan terjadi dalam sebuah kelas secara bersama (Arikunto, 2007). Kemudian PTK merupakan penelitian yang dilakukan oleh guru di kelasnya sendiri dengan cara merencanakan, melaksanakan, dan merefleksikan tindakan secara kolaboratif dan partisipatif dengan tujuan memperbaiki kinerja guru sehingga hasil belajar siswa dapat meningkat (Kusumah \& Dwitagama, 2010). PTK sebagai proses pengkajian masalah pembelajaran di dalam kelas melalui refleksi diri dalam upaya untuk memecahkan masalah tersebut dengan cara melakukan berbagai tindakan yang terencana dalam situasi nyata serta menganalisis setiap pengaruh dari perlakuan tersebut (Sanjaya. 2011). Arikunto (2006) menjelaskan bahwa dalam penelitian kolaborasi, pihak yang melakukan tindakan adalah guru kelas itu sendiri sedangkan yang melakukan pengamatan terhadap berlangsungnya proses tindakan adalah peneliti. Penelitian tindakan kelas ini dilakukan dengan tujuan untuk meningkatkan hasil belajar siswa melalui Pembelajaran Matematika Realistik dalam pembelajaran Matematika. Penelitian tindakan kelas yang digunakan dalam penelitian ini mengacu pada Model Kemmis \& McTaggrat yang terdiri dari empat komponen, yaitu perencanaan (planning), tindakan (acting), pengamatan (observing) dan refleksi (reflecting).

Subjek penelitian ini adalah siswa kelas VI A SDN Cigintung, Kecamatan Kuningan, Kabupaten Kuningan tahun pelajaran 2019/2020 yang berjumlah 25 siswa. Data dalam penelitian ini dikumpulkan melalui tes, observasi, dan dokumentasi.

\section{Hasil dan Pembahasan}

Penelitian Tindakan Kelas ini dilakukan di SDN Cigintung yang terletak di Jl. Raya Cigintung, Kecamatan Kuningan, Kabupaten Kuningan. Subyek penelitian pada penelitian tindakan kelas ini adalah siswa kelas VI A yang diampu oleh Ibu Tun Wahyuni. Jumlah siswa di kelas ini ada 25 siswa. Pelaksanaan Penelitian Tindakan Kelas pada mata pelajaran Matematika kelas VI A SDN Cigintung dilaksanakan dalam dua siklus. 
Data awal diperoleh dari tes pra tindakan yang akan dilaksanakan pada Jum'at, 6 September 2019 yang diikuti oleh 15 siswa kelas VI A SDN Cigintung. Perolehan nilai tes hasil belajar Matematika pra tindakan pada siswa kelas VI A SDN Cigintung dapat dilihat lampiran 3 halaman 105. Berikut disajikan tabel data pra tindakan.

Tabel 2. Analisis Tes Hasil Belajar Matematika Siswa Pada Pra tindakan

\begin{tabular}{cccc}
\hline No. & Kriteria & Jumlah anak & Persentase \\
\hline 1. & Tuntas & 5 & $20 \%$ \\
2. & Belum tuntas & 20 & $80 \%$ \\
\hline
\end{tabular}

Data dari tabel di atas mengenai hasil belajar Matematika siswa pada pra tindakan dapat diperjelas melalui diagram di bawah ini.

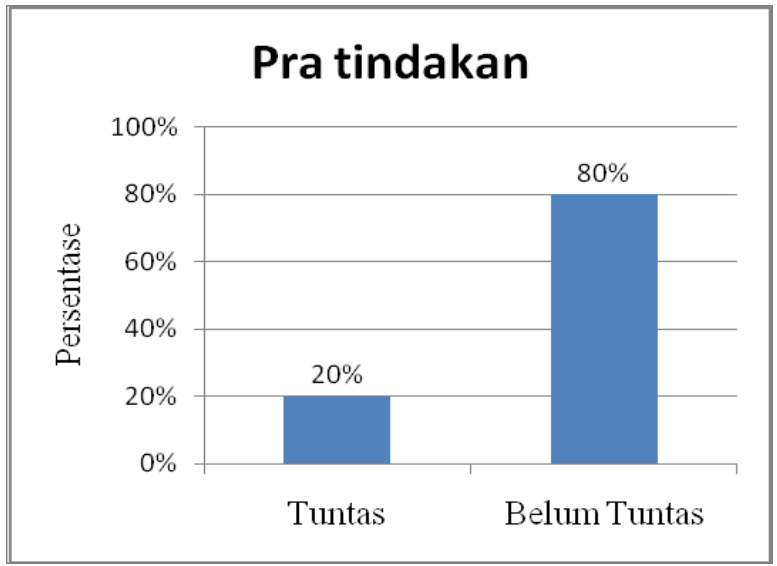

Gambar 1. Diagram Hasil Belajar Matematika Siswa pada Pra Tindakan

Berdasarkan hasil tersebut 20 siswa (80\%) siswa belum tuntas atau belum mencapai standar nilai KKM, hal ini menunjukkan bahwa siswa yang telah memperoleh nilai tuntas di atas KKM masih tergolong rendah yaitu hanya 5 siswa (20\%) dari total 25 siswa.

Penelitian Tindakan Kelas meliputi 2 siklus yang terdiri dari siklus I dan siklus II. Setiap siklus terdiri dari 2 kali pertemuan dan terdiri dari beberapa tahap, yaitu tahap perencanaan, tindakan, observasi, dan refleksi. Pada siklus II tahap-tahap yang dilakukan merupakan perbaikan pada siklus sebelumnya. Hasil yang diperoleh pada penelitian ini terdiri dari data tes yang berupa hasil belajar kognitif yang diperoleh melalui tes dan hasil belajar afektif berdasarkan hasil observasi sikap siswa menggunakan Pembelajaran Matematika Realistik. Hasil dari kedua siklus tersebut digunakan untuk mengetahui peningkatan hasil belajar Matematika dengan menggunakan Pembelajaran Matematika Realistik pada siswa kelas VI A di SDN Cigintung.

Hasil belajar pada siklus I dan II, berdasarkan tes dapat dilihat pada tabel 3.

Tabel 3. Persentase jumlah siswa yang tuntas belajar pada siklus I dan II

\begin{tabular}{ccccc}
\hline \multirow{2}{*}{ Kategori } & \multicolumn{2}{c}{ Siklus I } & \multicolumn{2}{c}{ Siklus II } \\
& Siswa & $\%$ & Siswa & $\%$ \\
\hline Tuntas & 13 & 53,33 & 20 & 80 \\
\hline
\end{tabular}




$\begin{array}{ccccc}\text { Belum tuntas } & 12 & 46,67 & 5 & 20 \\ \text { Jumlah } & 25 & 100 & 25 & 100\end{array}$

Berdasarkan tabel di atas dapat diketahui bahwa pada siklus II sebanyak 20 siswa atau $80 \%$ siswa dari seluruh siswa mendapatkan nilai $\geq 65$ dibandingkan data nilai siklus I yang hanya 13 siswa atau 53,33\%, sedangkan jumlah siswa yang belum tuntas adalah 5 siswa atau $20 \%$ siswa dari seluruh siswa mendapatkan nilai 65 . Berdasarkan hasil tersebut dapat dikatakan terjadi peningkatan 26,67\% jumlah siswa yang tuntas belajar dilaksanakan pada siklus II. Perbandingan hasil belajar pada Siklus I dan Siklus II diperjelas pada diagram batang sebagai berikut

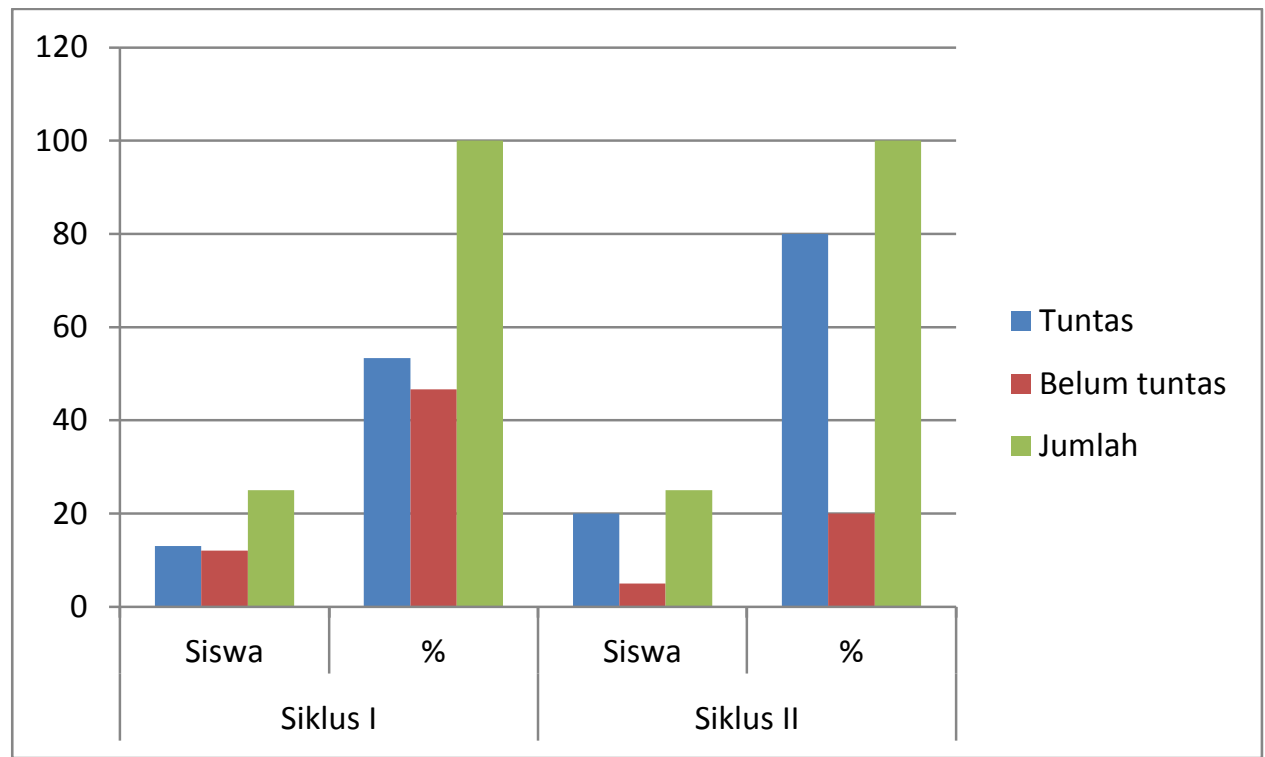

Gambar 2. Diagram Hasil Belajar Matematika Siswa pada siklus I dan II

Data yang diperoleh sebelum dan setelah dilaksanakan tindakan menunjukkan adanya peningkatan hasil belajar siswa yang ditunjukkan dengan hasil tes yang dipeoleh. Sebelum diterapkanya PMR dalam pembelajaran Matematika, diperoleh sebanyak 5 siswa atau 20\% siswa mendapat nilai $\geq 65$, sedangkan 20 atau $80 \%$ siswa mendapat nilai kurang dari 65 . Namun setelah pembelajaran melalui PMR pada siklus I dan II diperoleh data bahwa hasil belajar siswa meningkat. Hasil tes siklus I dipeoleh 13 atau 53,33\% dari seluruh siswa mendapat nilai $\geq 65$, sedangkan 12 siswa atau 46,67\% dari seluruh siswa belum mencapai nilai $\geq 65$. Berdasarkan data tersebut dapat dikatakan terjadi peningkatan 33,33\% jumlah siswa yang tuntas belajar pada tindakan siklus I. Kemudian pada hasil tes siklus II menunjukkan 20 atau $80 \%$ dari seluruh siswa tuntas dan 5 siswa atau 20\% siswa yang belum tuntas. Jika dibandingkan dengan prestasi belajar siklus I, mengalami peningkatan 26,67\% jumlah siswa yang tuntas belajar.

Ditinjau dari nilai rata-rata tes yang diperoleh siswa, saat dilakukan tes pra tindakan yaitu 4,47. Nilai rata-rata hasil tes pada siklus I yaitu 6,13 sedangkan nilai rata-rata tes siklus II yaitu 7,60. Berdasarkan data di atas, dapat diketahui bahwa terjadi peningkatan nilai rata-rata siswa dari pra tindakan, siklus I, dan siklus II. Setelah dilaksanakan tindakan siklus I rata-rata hasil tes meningkat 1,66 menjadi 6,13 dibandingkan rata-rata hasil tes sebelum diterapkanya 
PMR dalam pembelajaran. Kemudian nilai rata-rata hasil tes dari siklus I ke siklus II juga mengalami peningkatan 1,47 menjadi 7,60.

Selain dapat meningkatkan hasil belajar kognitif siswa, pendekatan Pembelajaran Matematika Realistik ini juga dapat meningkatkan hasil belajar afektif berupa peningkatan sikap siswa yang berlangsung di dalam kelas selama pembelajaran berlangsung. Pada saat observasi awal yang dilakukan peneliti pada pembelajaran Matematika di kelas VI A di SDN Cigintung, pada saat proses pembelajaran Matematika berlangsung, guru menyampaikan materi dengan ceramah dan sesekali mengajukan pertanyaan kepada siswa. Guru terlihat kurang melibatkan siswa dalam melakukan proses pembelajaran dan cenderung medominasi pembelajaran.

Pada siklus I dan II diterapkan pendekatan Pembelajaran Matematika Realistik. Masalah-masalah nyata dari kehidupan sehari-hari digunakan sebagai titik awal pembelajaran matematika untuk menunjukkan bahwa matematika dekat dengan kehidupan sehari-hari. Benda-benda nyata yang akrab dengan kehidupan sehari-hari dijadikan sebagai alat peraga yang dalam penelitian ini alat peraga untuk debit air sehingga siswa menjadi lebih tertarik. Hal tersebut senada dengan pendapat Hadi (Aisyah dkk, 2007) bahwa melalui PMR siswa menjadi lebih tertarik dan senang belajar matematika serta menunjukkan peningkatan hasil belajar yang cukup memuaskan.

Guru juga memberikan kesempatan kepada siswa melalui kegiatan diskusi, sehingga mendorong adanya interaksi antar teman maka pembelajaran memungkinkan siswa bersosialisasi dengan menghargai perbedaan pendapat dan berlatih untuk bekerja sama. Semakin sering dilaksanakan kegiatan diskusi dapat meningkatkan interaksi serta kerja sama. Hal ini menunjukkan adanya peningkatan partisipasi siswa pada setiap siklus, terjadinya peningkatan hasil belajar siswa tersebut merupakan hasil dari pembelajaran melalui PMR yang secara umum berjalan dengan baik seperti yang dilihat dari hasil pengamatan pada saat pembelajaran berlangsung. Dengan adanya kegiatan atau aktivitas untuk menemukan sendiri konsep matematika akan mendorong siswa untuk berpartisipasi aktif dalam aktivitas pembelajaran. Hal tersebut sesuai dengan pendapat Sugihartono (2007: 109) bahwa pengamatan sangat penting dan menjadi dasar dalam menuntun proses belajar oleh karena itu dalam belajar diupayakan siswa harus mengalami sendiri dan terlibat langsung secara realistik dengan obyek yang dipelajarinya.

Berdasarkan hasil pengamatan yang dilakukan oleh peneliti sebagai observer dapat dilihat bahwa siswa terlihat lebih aktif dari sebelum dilakukan tindakan. Hal tersebut dikarenakan pada pembelajaran Matematika Realistik guru memberikan pengalaman langsung kepada siswa dengan melakukan berbagai kegiatan yang menuntut siswa untuk aktif secara kognitif, afektif dan psikomotor. Untuk kemampuan kognitifnya siswa diberi tugas untuk menuliskan hasil dari penggunaan alat peraga. Hal tersebut dilakukan melalui diskusi kelompok. Setelah itu, guru memberikan kesempatan kepada masing-masing kelompok untuk mempresentasikan hasil diskusinya di depan kelas. Untuk mengulangi materi yang telah dipelajari guru memancing siswa dengan pertanyaan-pertanyaan singkat sehingga siswa mampu menyimpulkan sendiri materi yang telah dipelajarinya dan mampu membangkitkan motivasi siswa dalam belajar.

Berdasarkan beberapa paparan di atas disimpulkan bahwa penelitian tindakan kelas yang dilakukan dapat meningkatkan hasil belajar siswa kelas VI A di SDN Cigintung melalui 
pendekatan Matematika Realistik. Hal tersebut dibuktikan dengan adanya perubahanperubahan yang terjadi pada hasil belajar siswa.

\section{Simpulan}

Berdasarkan hasil penelitian yang telah dilaksanakan, maka dapat disimpulkan bahwa hasil belajar matematika siswa kelas VI A SDN Cigintung melalui Pembelajaran Matematika Realistik mengalami peningkatan. Pembelajaran siklus I dan II, guru menggunakan masalah kontekstual yang berkaitan dengan materi untuk memulai pembelajaran, siswa menggunakan alat peraga, mendiskusikan hasil penggunaan alat peraga, menemukan konsep berdasarkan hasil diskusi kemudian memperkenalkan prosedur baku untuk menyelesaikan masalah menggunakan rumus dan dalam pembelajarannya mengaitkan konsep lain dalam matematika yang berhubungan dengan materi.

\section{Daftar Pustaka}

Aisyah, dkk. (2007). Pengembangan Pembelajaran Matematika SD. Jakarta: Depdiknas Dirjen Dikti Direktorat Ketenagaan.

Arikunto. (2006). Prosedur Penelitian Suatu Pendekatan Praktik. Jakarta: Rineka Cipta.

Arikunto. (2007). Penelitian Tindakan Kelas. Jakarta: Bumi Aksara.

Atika, N., \& Mz, Z. A. (2016). Pengembangan LKS Berbasis Pendekatan RME Untuk Menumbuhkembangkan Kemampuan Berpikir Kritis Matematis. Suska Journal of Mathematics Education, 2(2), 103-110.

Azmi, M. P. (2017). Asosiasi Antara Kemampuan Analogi Dengan Komunikasi Matematik Siswa SMP. Al-Jabar: Jurnal Pendidikan Matematika, 8(1), 91-100.

Bidari, I. (2016). Pengaruh Habits Of Mind Terbadap Kemampuan Generalisasi Matematika Siswa. Jakarta: UIN Syarif Hidayatullah Jakarta.

Dolk, M., \& Eerde, D. Van. (2013). Developing a Local Instruction Theory for Learning the Concept of Angle through Visual Field Activities and Spatial Representations. International Education Studies, 6(8), 58-70. https://doi.org/10.5539/ies.v6n8p58

Fitriani, N., Suryadi, D., \& Darhim, D. (2018). The Students'mathematical Abstraction Ability Through Realistic Mathematics Education With Vba-Microsoft Excel. Infinity Journal, $7(2), 123-132$.

Hamalik. (2007). Kurikulum dan Pembelajaran. Jakarta: Bumi Aksara.

Hidayat, R., \& Iksan, Z. H. (2015). The Effect of Realistic Mathematic Education on Students' Conceptual Understanding of Linear Progamming. Creative Education, 6(December), 2438-2445. https://doi.org/10.4236/ce.2015.622251.

Indriani, L. F. (2018). Kemampuan Penalaran Matematis dan Habits Of Mind Siswa SMP dalam Materi Segiempat dan Segitiga. Jurnal Math Educator Nusantara, 4(2), 87-94. https://doi.org/10.29407/jmen.v4i2.11999

KTSP. (2007).Kurikulum Tingkat Satuan Pendidikan. Jakarta: BP Cipta Jaya

Kusumah \& Dwitagama. (2010). Mengenal penelitian Tindakan Kelas. Jakarta: PT Indeks.

Masni, E. D. (2017). Asosiasi Kemampuan Pemecahan Masalah dan Mathematical Habits of Mind Siswa SMP. Jurnal Penelitian Pendidikan INSANI, 20(1). 
Miliyawati, B. (2017). Reformulasi Strategi Habits Of Mind Matematis Terhadap Kemampuan Mathematical Critical Thingking Dalam Mewujudkan Generasi Emas Berkarakter. JNPM ( Jurnal Nasional Pendidikan Matematika ), 1(1), 24-42.

Nahdi, D. S., \& Jatisunda, M. G. (2020). Conceptual Understanding And Procedural Knowledge: A Case Study on Learning Mathematics of Fractional Material in Elementary School. Journal of Physics: Conference Series, 1477, 42037. https://doi.org/10.1088/1742-6596/1477/4/042037

Prihandoko. (2006). Memahami konsep matematika secara benar dan menyajikannya dengan menarik. Jakarta: Depdiknas Dirjen Dikti Direktorat Ketenagaan.

Rahman, R., \& Maarif, S. (2014). Pengaruh penggunaan metode discovery terhadap kemampuan analogi matematis siswa SMK Al-Ikhsan Pamacarian Kabupaten Ciamis Jawa Barat. Jurnal Ilmiah Program Studi Matrmatika STKIP Siliwangi Bandung, 3(1), 33-58

Rudiono, T., Dafik, \& Wahyuningrum, E. (2015). Pengembangan Perangkat Pembelajaran Berbasis Rme Berorientasi Terciptanya Berfikir Tingkat Tinggi Materi Perbandingan Kelas VII. Pancaran, 4(1), 45-54.

Sanjaya. (2011). Penelitian Tindakan Kelas. Jakarta: Kencana.

Subarinah. (2006). Inovasi Pembelajaran Matematika SD. Depdiknas: Jakarta.

Sugihartono, dkk. (2007). Psikologi Pendidikan. Yogyakarta: UNY Press.

Susanti, G., \& Rustam, A. (2018). The Effectiveness Of Learning Models Realistic Mathematics Education And Problem Based Learning Toward Mathematical Reasoning Skills At Students Of Junior High School. Journal of Mathematics Education, 3(1), 33-39.

Tarigan. (2006). Pembelajaran Matematika Realistik. Jakarta: Depdiknas

Wijaya. (2012). Pembelajaran Matematika Realisik. Yogyakarta: Graha Ilmu.

Zhok, A. (2016). Habit and Mind. On The Teleology of Mental Habits. Phenomenology and Mind, 0(6), 90-99. 